\title{
タバコ煙によるハムスター気道腫瘍の誘発
}

\section{Tumor Promoting Activity of Cigarette Smoke on the Upper Airway Epithelium in Hamsters}

小林延年

\begin{abstract}
抄録：Hamburg Type II 人口喫煙装置による夕バコの煙の吸入実験で，ハムスタ一気道にヒト 類似の扁平上皮癌を，比較的短期間に発生させ，またそれに至る前段階病変を多数例で 観察した。あらかじめ Dimethylbenzanthracene (DMBA)，240 $\boldsymbol{\mu g}$ を喉頭部に投与 したのち, 吸入を加えた群では, DMBA単独又は吸入単独群に比して, 気道腫瘍の形成 率は著明に高まった。新鮮煙に上る喫煙の負荷は，それ自身の発癌性よりも発癌を促進 させる特性の強いことが示された。
\end{abstract}

種々の化学物質により実験的に肺癌を作製す ることは今日それ程困難ではなくなり，各種の 癌原性炭化水素, 2)3 ${ }^{1 / 2}$ 二トロソ化合物, 放射性物 質，）その他の癌原物質による実験的肺癌の報告 も数多く見られる様になった。ヒト同様の疾患 モデルを作成することはその病因解明のための 重要な鍵と云える。しかし現在までの肺癌作成 法は気道, 肺と云う臓器の特殊性に伴う困難さ のため種々の人工的な工夫がこらされている. 即ち癌原物質の経気道投与に carrier dust, ${ }^{1)}$ 皮 下投与には脂質の solvent, ${ }^{6)}$ 局所投与にペレー ${ }^{7)}$ の使用などである。再にこれらの発生実験に使 用される癌原物質は極度の大量であり, ヒトの 環境に対比して腫瘍発生のメカニズムを考察し 得る範囲のものではない．実験的肺癌の作成が 比較的容易に可能となりつつある今， 七ト肺癌 の発生の真因を見出してゆくため実験の setting を人間が置かれ得る条件に近づけ実験結果の解 釈をヒト肺癌発生のメカニズムに対する知識を 増すべく努力がなされるべきであろう。一方， 近年に於ける我国の肺癌の急増は, 約30年の差 を持って欧米諸国のそれと対比される。この環

千葉大学医学部肺癌研究施設外科
境要因の一つとして契煙の関与が挙げられ，夕 バコタールの発癌性に関する実験 ${ }^{8)}$ はこれに支 持を与えている。にもかかわらず肺癌の発生が 夕バコ喫煙を原因とするデータは目下の所疫学 によるのみで夕バコの煙によって気道の扁平上 皮癌を動物に於いて実験的に再現し得ず吸入に よる気道腫瘍の発生実験には残された問題が多 い.我々は先にHamburg Type II 人工喫煙装置 を用いハムスタ一上気道の腫瘍形成促進の現象 を観察した ${ }^{910)}$ 更に実験を重ねて，この現象を 確認すると共に，気道上皮の癌化えの種々相を 観察し得たのでその病理組織学的変化について述 べ，本法による実験の意義について考察を加え る.

\section{材料並に方法}

動物はSyrian Golden Hamster (体重90 g 前 後）を雌雄同数用い実験群は表 1 に示す.夕バ コは米国製市販紙巻で $85 \mathrm{~mm}$ 両切のものを用いた。 Dimethylbenz (a )anthracene(DMBA)はクロ マトグラフィーにより純化, Dimethylsulfoxide (DMSO) に溶解し $10 \mu \ell に 120 \mu \mathrm{g}$ のDMBA を含む 様調整した。

Group I：動物はエーテル麻酔下に Hammilton syringeによりDMBA120 $\boldsymbol{\mu g}$ を喉頭蓋後壁部 
表 I
I. DMBA/DMSO $120 \mu_{\mathrm{G}} \times 2+$ SMOKE
II. DMSO
+ SMOKE

(40)

(20)

III. SMOKE ALONe

IV. DMBA/DMSO $120 \mu \mathrm{M} \times 2+$ ShAM SMOKE

(20)

に滴下(週 1 回 2 週) lnitiationとしその10日後よ り人工喫煙装置により 1 日 2 回，週 5 日間の喫 煙負荷を開始した。

Group II : Group I と同様に solvent DMSO のみの処置を行ない，以後，I 群と同じく喫煙 を負荷し対照とした．Group III：上記の喫煙負 荷のみの群. Group IV：I 群と同じDMBAの処置 を行ない，10日後よりフィルターチップのみの sham smokingを全く同様に行ない対照群とし た. Hamburg Type IIについては既に記したが, 9, 10) 略記すると回転式で各夕バコは 1 分間に 1 回， 2 秒間 $35 \mathrm{~m} \ell$ 吸煙し，空気との混合比は 1 ： 7 とした。いわゆる標準哭煙法である。動物は 経過中衰弱時には屠殺し，喫煙群は48週続けそ の 4 週後即ち吸入開始後52週で他の群と共に全 例犠牲死せしめ, 全身臟器の検索と共に上顎, 鼻腔より脱灰して 3 ブロック，喉頭部は水平断 の 3 ブロックとし, 各々連続切片により通常の 病理組織学的検索に供した。

\section{実験結果}

体重の増加について見ると吸入開始後15週よ り全吸入群( G I II III) 共, 非喫煙対照群に比し 有意の差で下廻っている(図 I )。本法に於ける 腫瘍性增殖の標的部位が喉頭部にある事は既に 前報 ${ }^{9)} に$ 記した。本実験でも癌性変化は喉頭蓋 後壁，喉頭前庭部，声門に最も高頻度に見られ た(図 2 )。この部の増殖性変化の程度をGrade $\mathrm{I} \sim \mathrm{V}$ の 5 段階に分け死亡順にプロットしたも のが図 3 である。吸入開始後 4 群夫々に死亡率 に大きな差は見られない.Grade I：標的部の 線毛円柱上皮は扁平上皮化生及び角化層も厚い pachydemia を示す (写真 2 ). Grade II : 基底 層の増生が著しく nodular hyperplasia を示し垂 根状増殖，或いは粘膜層の乳嘴状変化，増殖に
図I. Body Weight Curves

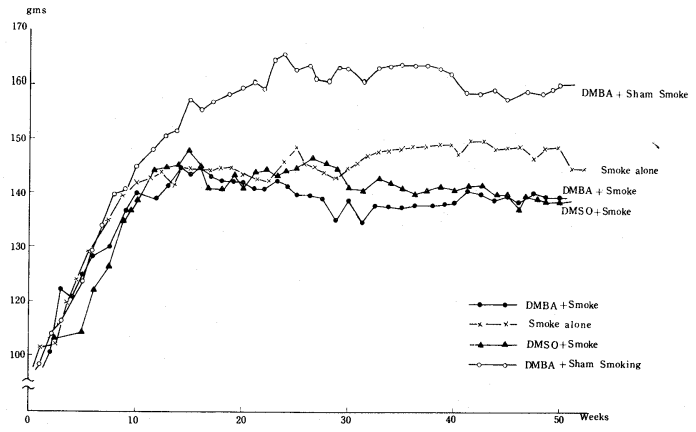

図2. Neoplastic Changes in Larynx

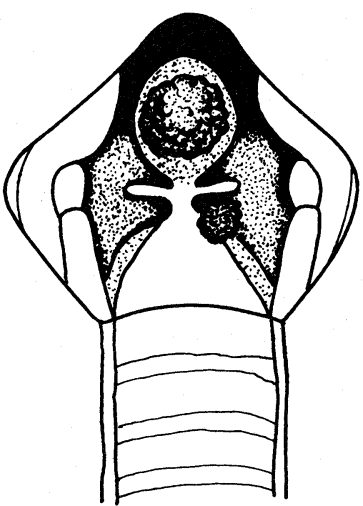

図3. Epithelial Changes in Larynx

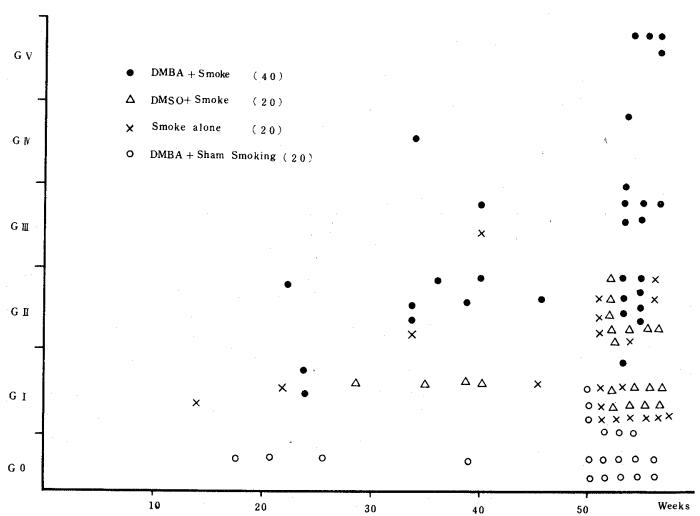

伴う変形（写真 3 ）。 Grade III：内腔面に向う papillama(写真 4 )及び粘膜下層に向う inverted papilloma. Grade IV : in situ carcinomaに上 述の変化を伴う(写真 5 ). Grade V : 周囲組織 え浸潤の著しい癌腫(写真 6,7 )。発生した癌 腫はGroup I で 4 例全て扁平上皮癌であり，40 
Fig. 1. Horizontal section of the normal larynx in a hamster (Grade 0). Two types of epithelium line the wall of the larynx: ciliated columnar and squamous.

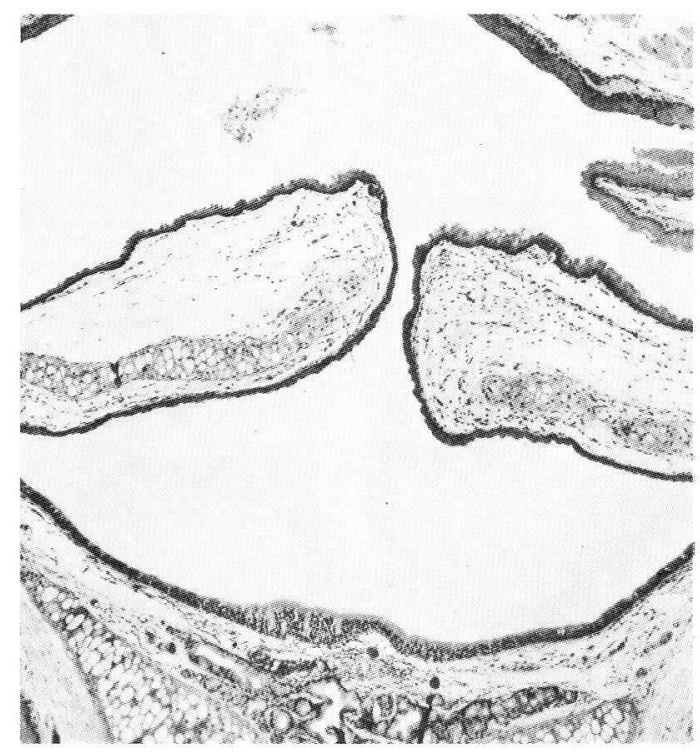

例中13例33\%に papilloma, cancer の発生が見ら れた。これに対してGroup II, IIIの吸入群では 喫煙単独群の 1 例のポリープ様 pappilloma を除 いてすべてGrade II 以下の変化を示している。 対照としたGroup IV ではminimum metaplasia が 少数例に見られたが殆んど正常喉頭組織を示し た。咽頭部の変化：Group Iでは一般に粘膜肥 厚し，基底細胞層の著明なdown growthを示す もの 3 例, 喉頭隣接部に papilloma 18, 浸潤癌 (扁平上皮癌) 3 例を認めた。Group IVでは粘膜 肥厚, 基底細胞層増生を示すもの 4 例, papilloma 5 例. 食道: Group I では, papilloma 8 例, GroupIVにはpapilloma 5 例, 胃: multiple papilloma, Group I 34, Group IV 16, GroupIII 1. 以上 GroupIVの所見はDMBAのみに対する咽頭から 前胃の消化管粘膜上皮の basic response を示し ている。この他Group I では硬口蓋に壤死性潰 瘍, pseudoepitheliomatous hyperplasia を各 一例認めた。肺内の変化は吸入を行なった I 一 III群に褐色のpigment有するdust cell の集族 が肺胞内に散在するものが各群数例に見られた
Fig. 2. Squamous cell metaplasia with keratin formation in the larynx (lower posterior wall of the epiglottis) (Grade I).

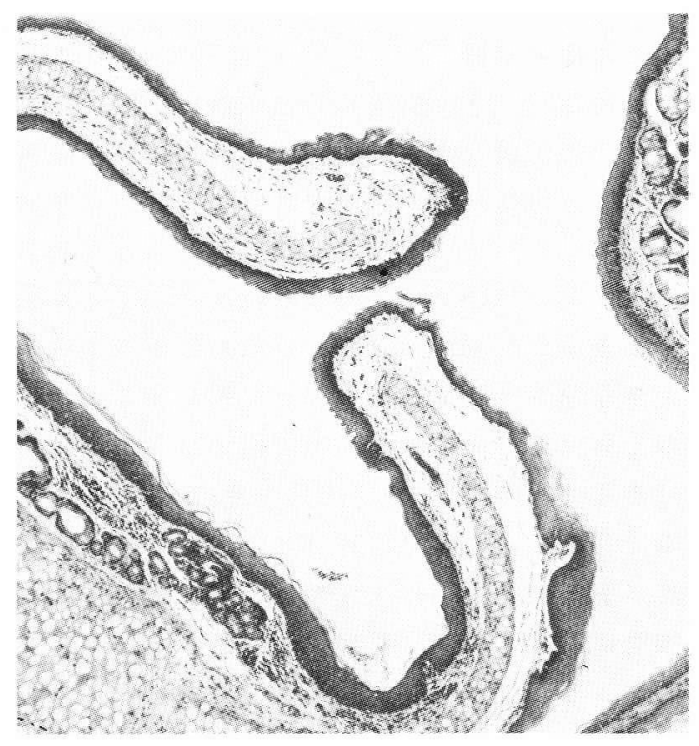

Fig. 3. Squamous cell metaplasia of the larynx showing nodular hyperplasia of basal cells resulting irregular mucosal thickening (Grade II).

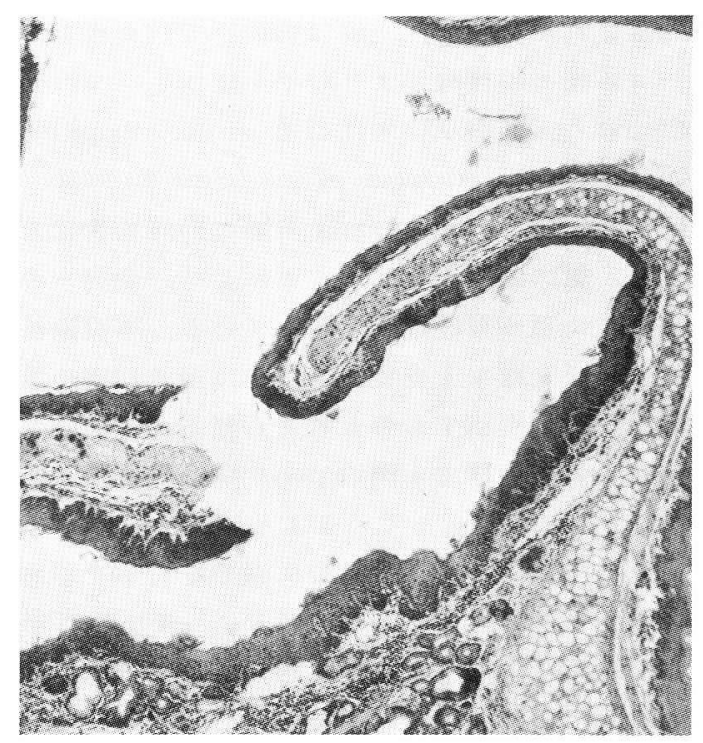

が気管支上皮に増殖性，腫瘍性の変化は認めら れなかった。その他の変化：Group I に2例の副睪 丸膿瘍, 副腎腺腫1, 卯巣囊腫1. Group II に副睪 丸膿瘍 1 , 卵巣囊腫( Tarry cyst) 2 , Group III に副 
瞕丸膿瘍 1 , 卵巣囊腫 1 , 前胃パピローム 1 。

Sham smokingの対照群(GroupIV)にはこれ らの変化は認められていない。

\section{まとめと考按}

Hamburg Type II を用いた実験によると，タ バコの煙が最も高濃度に接触する部分は喉頭蓋 後壁より声带に及ぶ組織であることは既に示め されている.910)11) 喉頭部は標的部位となり得る が肺内及び鼻腔では表面積の拡がりによる稀釈 と線毛上皮の clearance activity により上皮の 変化を起させる煙の量は極为て不足するものと 考えられる。そこで今回の実験では，気道に於 けるこの喉頭上皮 (線毛円柱上皮部)をテストの 場として設定し発癌に於ける二段階法 ${ }^{12)}$ を応用 し，気道の線毛円柱上皮がタバコ煙との直接の 接触により，どの様な形態学的変化を起すかを 観察することを目的とした，又，それによって いろいろな条件下での夕バコ煙の腫瘍原性とし ての活性, 腫瘍発生の促進能をテス卜方るため のBioassay法をどの様にすべきかを探るためで も亦る。

本実験から明らかに示された様に，DMBAで 処置された線毛円柱上皮は引続いて送られる夕 バコの煙との接触により扁平上皮化生（pachydermia ) $\rightarrow$ 乳嘴状化生性増殖 $\rightarrow$ pesudoepithe liomatous hyperplasia $\rightarrow \mathrm{Ca}$ in $\mathrm{Situ} \rightarrow$ invasive squamous cell caricinoma の順に経時的変化を 示し，更に吸入を続けることにより，全例が癌 性変化に至る可能性を示唆している。本実験法 に上る限り扁平上皮化生は癌化に至る初期の重 要な一段階を示すものと考えられる。対照群及 ぜ吸入のみの群で 1 例の polyp 様変化を除き,

Grade IIに止どまっていることはsmoke 単独で は極めて弱い癌原性を持つに過ざない事を示す ものであろう。しかしDMBAによって initiation を受けた線毛円柱上皮は，その後の smoke inhalationによって上述の形態学的変化を経て本 実験期間の範囲でも明らかに腫瘍性変化の誘発 を促進されている. 又, pachydermia 以上の変 化は吸入中止後 4 週間以内では irreversible で あったと考えられる。 Morphogenerisの詳細は
Fig. 4. Papilloma of the larynx (Grade III).

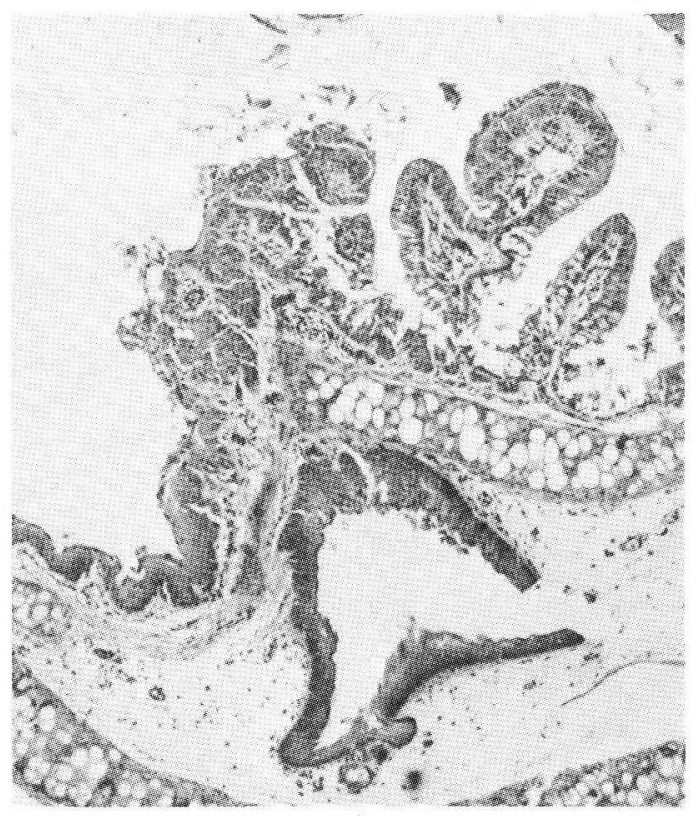

Fig. 5. In site carcinoma in the larynx (Grade IV).

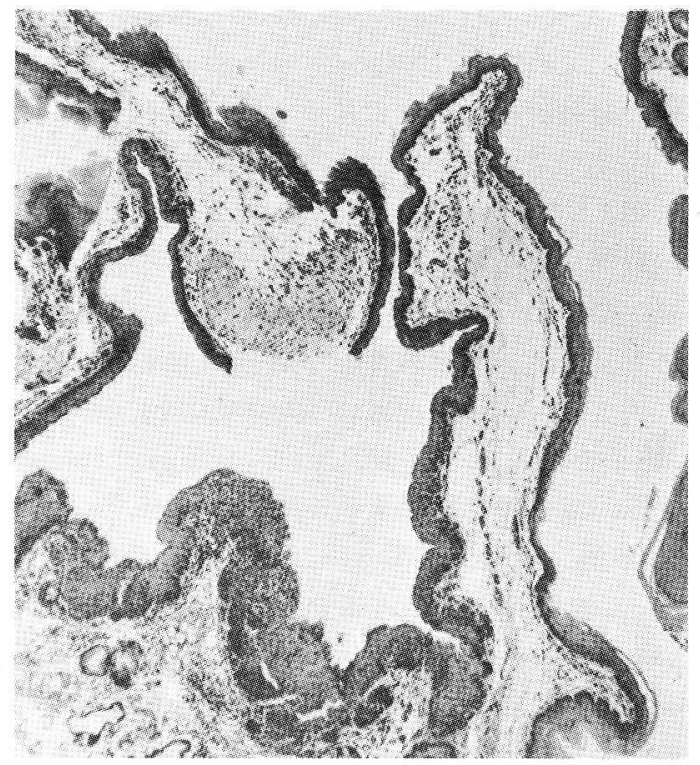

は別に項を改めて報告したいと思う。

タバコタールの発癌性は種々の動物, 組織に

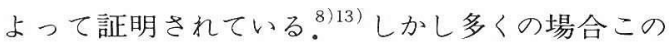
タール量は極めて大量であり，又，テストの場 
Fig. 6. Squamous cell carcinoma of larynx with papillary tumor mass, invading sorounding tissue (Grade V).

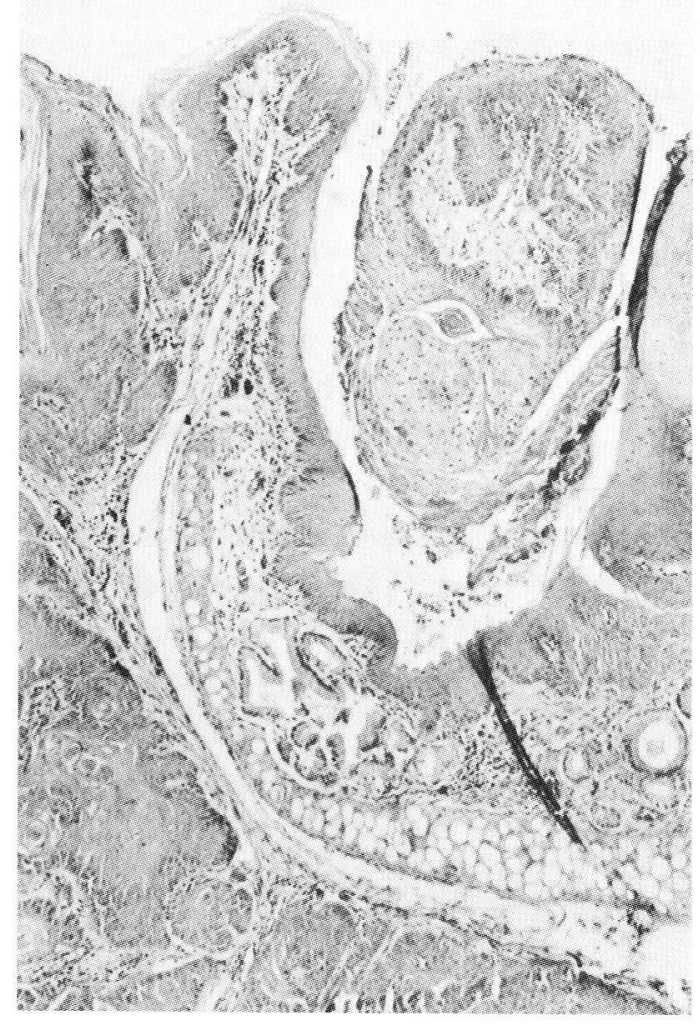

も皮膚, 皮下組織である。環境発癌因子として のタバコ煙をテストする場合, その生物学的活 性テストの場は気道上皮が望ましいのは当然で あろう。本実験法に於いても七ト肺癌に対比さ れるべき気管支上皮に変化を見出し得なかった が，喉頭とは云え気道に於ける線毛円柱上皮組 織にヒト扁平上皮癌と同一の腫瘍像とそれに至 る連続性の形態学的変化を把握し得た点で, ヒ トの気道に於ける扁平上皮癌の組織発生と, 将 来, cigarette smoke の腫瘍原性としての諸特 性を解明して行く上で寄与するものがあろうと 考える。即ち，エアロゾールとしてのタバコ主 煙流の carcinogenic activityに対する気道上皮 の最も現実的な反応様式を示古ものであろう。

次に実験の細目に於ける $2 \cdot 3$ の問題点をの ベる、鼻孔から吸入されたタバコ constituents は表面積の広い鼻腔内では particleの沈着密度
Fig. 7. Details of the same area. Tumor cells are anaplastic but keratinisation is existed.

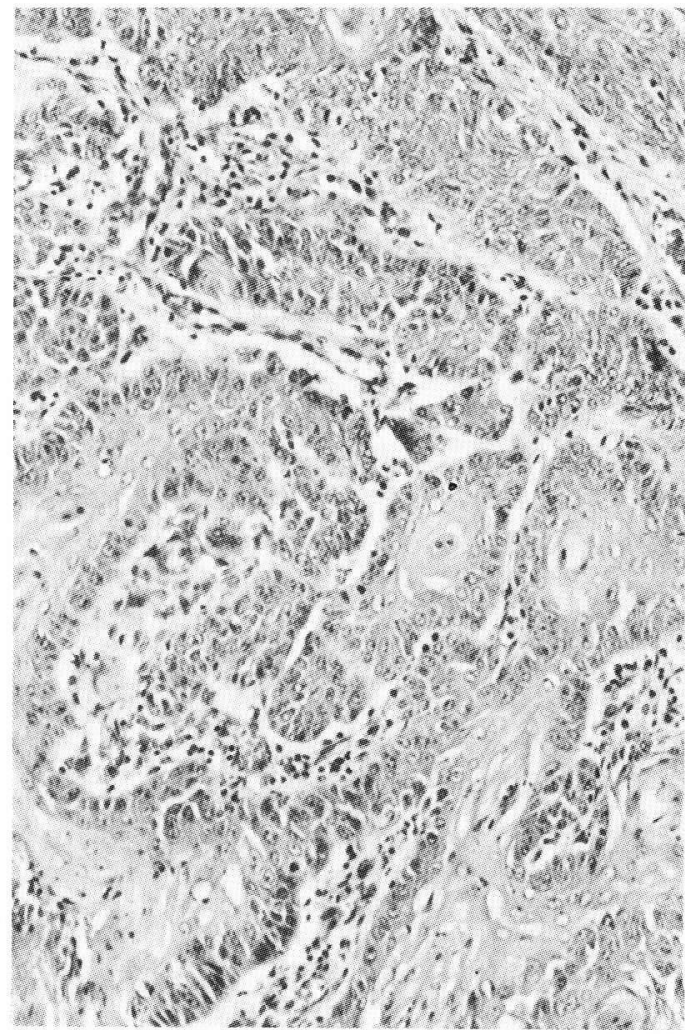

を減ずるが，この煙は動物の換気運動により流 体力学的にこの気流が再び流速を増したエアロ ゾールとして喉頭部並びに咽頭部に接触し，単 位面積当りの沈着密度を增子。そして肺内では 鼻腔に於けると同じ理由で減少すると考えれば, 喉頭部に於ける腫瘍性変化が吸入回数の増加に 従い高度となる dose-response を示すことにな る。DMSOは溶剂としてDMBAの完全溶液であ り喉頭部のみに比較的正確なdoseとして投与し 得, しかも組織浸透力の優れた点で利点がある。 しかし刺戦性である点は難点であり，10 $\mathrm{\mu l}$ の少 量でも喉頭の防禦反応により一部は嬹下され前 胃，食道のmultiple papilloma を発生させるもの と思われる。又，咽頭部の粘膜上皮は，同様の 機転で initiateされ引続く smokingによってGroup Iに於けるこの部の腫瘍性変化は喉頭に於ける と同じ傾向を示しパピローム，及invasive cancer 
等の腫瘍性変化の程度は高度となり対照群に比 して有意に上昇する結果を示したものと考えら れる。

気道に於ける“Initiation"の形態学は末だ不明 であるが taget となる線毛円柱上皮の数コがそ れによって dormant tumor cellに変じていれ ば煙吸入による腫瘍発生の促進, 又は協力の現 象が現れるものと推測される。従って今回用い た $240 \mu \mathrm{g}$ 以下の微量のDMBA であってもこの関 係は再現し得るものと考えている，人工契煙実 験に於いては，七ト契煙に最も近似させるため， 喫煙の持続時間，量，及び吸煙間隔を可及的人 間のそれに近づけ条件を一定にする必要があろ う。この点ではHamburg Type II は最大公約数 的な標準契煙条件を満たしている。又この条件 下で 1 日 2 回の吸入によっても体重の増加は見 られなかったが, 死亡率は低く対照群に比して差 はなく，長期実験にも耐え，その毒性は非現実 的なものと考えなくても良いであろう。

結論と今後の問題点：実験結果が示す事実は マウス皮䖉に対するタール塗布実験で示された tumor promotion ${ }^{14) 15) 16)}$ の現象と同様に whole smokeが気道上皮に対しても同様の tumor promotionを起させる特性を示した。この aerosol の 構成成分がどの様に気道内に分布し，どの構成 成分がこの特性を強く持つか又, どれだけの量 が単位面積の気道上皮組織に接触することによ ク不可逆性の癌化に至るか今後検索する必要が ある。扁平上皮化生は smoke に対する線毛円柱 上皮の初段階の変化で,これと微粒子, ガスがど の様な機作で増殖性変化に至らしめるか等残さ れた問題は多い. 更に passive inhalation の隘 路である吸入による“肺癌”作成の困難性を克服 し，ヒト同様の肺癌の再現を可能にするべく工 夫が必要であろう。

Tabacco Carcinogenesisの研究は単にタバコ 発癌のためではなく, 吸入される諸種の化学物 質を含む外来因子に対する気道上皮の反応，そ の機作を知るための晋辺的な問題を内包している.

(本稿の一部は第16回日本肺癌学会総会にて 発表した。)

\section{文 献}

1) Saffiotti, U., et al: Cancer Res. 28: 104-124, 1968.

2) Hirao, H., et al: Gann 59: 497-505, 1968.

3）中島英夫他, 肺癌, 15:53-59, 1975.

4) Dontenwill, W., et al:Z. Krebsforsch. 64: 305-312, 1961.

5) Little, J.B., et al: Cancer Res. 34: 3026-3039, 1974 .

6) Mori, K.: Gann 55: 175-182, 1964.

7) Stanton, M. F., et al: J. Natl Cancer Inst. 49:867-877, 1972.

8) Wynder, E. L., et al: Cancer Res. 13: 855864, 1953.

9) Kobayashi, N., et al: J. N. Natl Cancer Inst. 53: 1085-1089, 1974.
10）小林延年他, 医学のあゆみ，93: 139-144, 1975.

11). Dontenwill, W., et al: J. Natl Cancer Inst. 51: 1781-1832, 1973.

12) Wynder, E. L., et al: Tobacco and Tobacco Smoke, Studies in Experimental Carcinogenesis. 1967 Academic Press Inc., New York.

13) Druckrey, H.: Acta Medica Scandinavia 170 (Supplement 369), 24-42, 1961.

14) Wynder, E. L,. et al: Cancer 24: 289-301, 1969.

15) Gellhorn, A.: Cancer Res. 18: 510-517, 1958.

16) Van Duuren, B. L. et al: J. Natl Cancer Inst. 47: 235-240, 1974. 


\title{
Tumor Promoting Activity of Cigarette Smoke on the Upper Air Way Epithelium in Hamsters
}

\author{
Nobutoshi Kobayashi, M.D. \\ Division of Surgery, Institute of Pulmonary Cancer Research \\ School of Medicine, Chiba University
}

Four groups of Syrian Golden hamsters were treated as follows: Group I was exposed to cigarette smoke (Hamburg type II machine) after intralaryngeal initiation of total $240 \mu \mathrm{g}$ 7,12-dimethylbenzanthracene (DMBA); Group II was treated as vehicle alone controls followed by smoke exposure: Group III was exposed to cigarette smoke without the initial dose of initiation. Group IV received DMBA and sham smoked.

The animals received a combination of DMBA and smoke exposure developed after 52 weeks various reoplastic changes including 4 epidermoid carcinomas in a significantly higher incidence and earlier than other control groups. These findings lead to the conclusion that promoting agents or cocarcinogens have an important function in cigarette smoke carcinogenesis in major respiratory tract. 